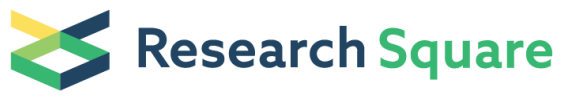 \\ Preprints are preliminary reports that have not undergone peer review. \\ They should not be considered conclusive, used to inform clinical practice, \\ or referenced by the media as validated information.
}

\section{LncRNA AWPPH as a Prognostic Predictor in Human Cancers: Evidence From Meta-analysis}

\author{
Yongfeng Li \\ Institute of cancer research and basic medical sciences of Chinese Academy of Sciences (Zhejiang Cancer Hospital) \\ Xinmiao Rui \\ Zhejiang Chinese Medical University \\ Daobao Chen \\ Institue of cancer research and basic medical sciences of Chinese Academy of Sciences (Zhejiang Cancer Hospital) \\ Haojun Xuan \\ Institute of cancer research and basic medical sciences of Chinese Academy of Sciences (Zhejiang Cancer Hospital) \\ Hongjian Yang \\ Institute of cancer research and basic medical sciences of Chinese Academy of Sciences (Zhejiang Cancer Hospital) \\ Xuli Meng ( $\nabla$ xulimeng2020@126.com) \\ Institute of cancer research and basic medical sciences of Chinese academy of sciences(zhejiang cancer hospital)
}

\section{Research article}

Keywords: long noncoding RNA, AWPPH, prognosis, meta-analysis

Posted Date: December 7th, 2020

DOI: https://doi.org/10.21203/rs.3.rs-121126/v1

License: (1) This work is licensed under a Creative Commons Attribution 4.0 International License. Read Full License 


\section{Abstract}

Background: Long noncoding RNA associated with poor prognosis of hepatocellular carcinoma (AWPPH) is a novel oncogene and dysregulated in a variety of human cancers. It has been revealed to be associated with the clinicopathological features and prognosis. However, the prognostic value of AWPPH in various cancers remains unclear. Therefore, we perform this meta-analysis to evaluate the relationship between AWPPH expression and clinical outcomes in human cancers.

Methods: Comprehensive literature search was performed in PubMed, Web of Science, CNKI and Wangfang databases, and eligible studies were obtained according to the inclusion and exclusion criteria. The pooled hazard ratios (HRs) and odds ratios (ORs) were applied to assess the clinical value of AWPPH expression for overall survival (OS) and clinicopathological features.

Results: A total of 19 articles including 1699 cancer patients were included in the study. The pooled results demonstrated that evaluated AWPPH expression was positively related to a poorer overall survival of patients with cancers $(\mathrm{HR}=1.79,95 \% \mathrm{Cl}$ : 1.44-2.14, $\mathrm{P}<0.001)$. Subgroup analysis revealed that tumor type and sample size affect the predictive value of AWPPH on OS, whereas cut-off value and HR estimation method have no impact on it. In addition, the pooled data also showed that AWPPH was positively linked to advanced TNM stage (OR=2.67, 95\%Cl: $1.86-3.83$, $\mathrm{P}<0.001)$, bigger tumor size $(\mathrm{OR}=2.64,95 \% \mathrm{Cl}: 1.47-4.73, \mathrm{P}=0.001)$, macro-vascular invasion $(\mathrm{OR}=2.08,95 \% \mathrm{Cl}$ : 1.04-4.16, $\mathrm{P}=0.04)$ and lymph node metastasis $(\mathrm{OR}=2.68,95 \% \mathrm{Cl}$ : $1.82-3.96, \mathrm{P}<0.001)$. Moreover, the results of the trim and fill analysis confirmed the reliability of our finding.

Conclusions: Upregulation of AWPPH was associated with advanced TNM stage, bigger tumor size, worse lymph node metastasis, macro-vascular invasion, and shorter overall survival, suggesting that AWPPH may serve as a biomarker for prognosis and clinicopathological characteristics in human cancers.

\section{Background}

Cancer has already become a major threat for human health in the world, and it has been the leading cause of death in China since 2010[1]. Cancer is a complex disease caused by a variety of molecular changes, including chromosomal translocations, deletions and amplification, epigenetic alterations and genetic mutations [2-4]. Although numerous progress has been achieved in the diagnosis and treatment of human cancers over the past decade, the clinical prognosis remains relatively worse in most cancer patients, mainly owing to the lack of effective biomarker to early diagnose cancer and predict clinical prognosis of cancer patients.

LncRNAs are a typical kinds of ncRNAs with more than 200 nucleotides, which have been proved to play a crucial role in tumorigenesis and tumor progression. Except for a few IncRNAs translate into proteins to involve in cellular and physiological processes, most IncRNAs transcripts directly or indirectly modulate transcriptional and posttranscriptional processes [5]. Moreover, many IncRNAs could serve as enhancers [6], splicing regulators [7], chromatin remodelers [8], and so on. Notably, growing evidence suggested that dysregulated IncRNAs occurred in a broad spectrum of human cancers $[9,10]$, and participated in cancer initiation and progression, indicating the potential value as clinical biomarkers and therapeutic targets. Recently, a new discovered IncRNA NSHG20 has drawn increasing attention.

Long noncoding RNA associated with poor prognosis of hepatocellular carcinoma (AWPPH), also well-known as AK001796, MIR4435-2HG, LINC00978 and other names, localized at 2q13, is dysregulated in broad ranges of cancers. Increasing evidence from fundamental and clinical studies demonstrated that AWPPH involved in tumorigenesis and exhibits poor prognostic value in many cancers, such as hepatocellular carcinoma [11], non-small cell lung cancer [12], and ovarian cancer [13]. However, most studies reported the prognostic value of AWPPH in cancer patients was limited by small sample size and discrete clinical outcome. Therefore, we conducted this systematic review and quantitative metaanalysis to investigate the prognostic value of AWPPH in human cancers.

\section{Methods}

\section{Search strategy}

We comprehensively searched in PubMed, Web of Science, CNKI and Wangfang database for eligible studies which reported the relationship between IncRNA AWPPH and OS before October 5, 2020. A combination of the following subjects was applied for the online search: ("carcinoma" OR "cancer" OR "tumor" OR "neoplasm") AND ("prognosis” OR “outcome” OR "diagnosis" OR "survival”) AND ("AWPPH" OR “LINCO0978” OR “MIR4435-1HG" OR “MORRBID” OR “AGD2" OR “MIR4435-12HG” OR “AK001796”). The reference lists of primary publications were also manually searched to obtain potential eligible studies.

\section{Inclusion and exclusion criteria}

We used the following inclusion criteria for eligible studies: 1) Studies reported the relationship between AWPPH and prognosis in human cancers; 2) Available data for HRs and corresponding $95 \% \mathrm{Cl}$ extraction; 3 ) patients were divided into high and low expression groups based on the 
expression of AWPPH. The following articles were excluded from the study: 1) reviews, letters, or case reports; 2) non-human studies; 3) duplicated publication.

\section{Data extraction and quality assessment}

The essential information was screened and extracted from each eligible study by two researchers (Li and Rui) independently, including the name of first author, year of publication, origin country, cancer type, sample size, detection method of AWPPH, HR and corresponding $95 \% \mathrm{Cl}$ for OS, as well as clinicopathological features. The HRs with $95 \% \mathrm{Cls}$ were obtained directly from eligible studies carried out the multivariate analysis. For those studies without multivariate analysis, HRs and $95 \% \mathrm{Cls}$ were calculated based on the survival curve according to the method described in the previous publication [14]. The Newcastle-Ottawa Scale (NOS) was applied to evaluate the quality of the included study.

\section{Statistical analysis}

The present meta-analysis was performed with Stata SE15.0 (Stata Corporation). HR and corresponding 95\%Cl for OS were applied to determine the pooled effect, and the odds ratio (OR) were used as the outcome estimation for data pooling. The fixed-effect model was selected while heterogeneity exists $(12>50 \%$ and $p<0.05)$, otherwise, the random-effect model was applied. Begg's funnel plot and egger's regression test were used to assess the publication bias. P-value $<0.05$ was considered as statistical significance.

\section{Results}

\section{Summary of eligible studies}

The detailed literature selection is shown in Fig. 1. A total of 153 potentially relevant articles were identified in this meta-analysis. 57 duplicate articles and 60 irrelevant articles were excluded after screening the titles and abstracts. Finally, 19 eligible studies were included owing to the lack of sufficient data in the other 7 articles. The characteristics of the included 19 studies were summarized in Table 1. A total of 1699 patients from 19 studies between 2016 and 2020 were included [11-13, 15-30]. All of the included studies were conducted in China. The study sample size ranged from 36 to 195 patients, and 12 studies enrolled more than 70 patients. The types of carcinoma included hepatocellular carcinoma (HCC, $n=3)$, colorectal adenocarcinoma (CRC, $n=3)$, ovarian carcinoma $(O C, n=2)$, triple-negative breast cancer $(T N B C, n=1)$, non-small cell lung cancer (NSCLC, $n=2)$, osteosarcoma $(n=1)$, cervical cancer $(C C, n=1)$, oral squamous cell carcinom $($ OSCC, $n=1)$, clear cell renal cell carcinoma (CCRCC, $n=1), G C(n=1)$, prostate carcinoma $(P C, n=1)$, breast cancer $(B C, n=1)$, esophageal squamous cell carcinoma $(E S C C, n=1)$. The level of AWPPH expression was detected by quantitative real-time polymerase chain reaction (qRT-PCR) in all included studies. Multivariate analysis was performed in 4 studies. Clinical outcomes were recorded including 19 studies for OS, 3 for RFS, 1 for PFS, and 1 for DFS. HRs with corresponding $95 \%$ Cls were extracted from the original data in 4 studies, and calculated from survival curves in the other 15 studies. Clinicopathologic features were also recorded in 15 studies including differentiation status, TNM stages, tumor size, macro-vascular invasion (MVI), lymph node metastasis (LNM) and distant metastasis (DM). In addition, all studies were more than 6 according to the NOS score criteria, indicating a high quality of the studies. 
Table 1

Characteristics of the included eligible studies.

\begin{tabular}{|c|c|c|c|c|c|c|c|c|c|c|}
\hline Author & Year & Country & Tumor & $\begin{array}{l}\text { Sample } \\
\text { size }\end{array}$ & $\begin{array}{l}\text { Cut-off } \\
\text { value }\end{array}$ & $\begin{array}{l}\text { Detection } \\
\text { method }\end{array}$ & Outcomes & $\begin{array}{l}\text { HR } \\
\text { estimation } \\
\text { method }\end{array}$ & $\mathrm{HR}(95 \% \mathrm{Cl})$ & NOS \\
\hline $\begin{array}{l}\text { Zhao } \\
\text { XD }\end{array}$ & 2017 & China & $\mathrm{HCC}$ & 88 & Median & qRT-PCR & OS/RFS & $\mathrm{U} / \mathrm{M}$ & $\begin{array}{l}\text { OS:3.509(1.574-7.820) } \\
\text { RFS:2.579(1.425- } \\
4.668)\end{array}$ & 8 \\
\hline Liu CC & 2018 & China & $\mathrm{CRC}$ & 86 & Median & qRT-PCR & OS & Indirectly & $1.51(0.74,3.07)$ & 8 \\
\hline Yu GY & 2019 & China & $\mathrm{OC}$ & 58 & Median & qRT-PCR & OS & Indirectly & $2.05(1.01,4.14)$ & 7 \\
\hline $\begin{array}{l}\text { Wang } \\
\text { KN }\end{array}$ & 2018 & China & TNBC & 68 & Median & qRT-PCR & os & Indirectly & $1.79(0.90,3.59)$ & 8 \\
\hline $\begin{array}{l}\text { Song } \\
\text { Z }\end{array}$ & 2018 & China & NSCLC & 88 & Median & qRT-PCR & os & Indirectly & $\begin{array}{l}\text { Tissue: } 1.78(0.99,3.20) \\
\text { Serum: } 1.66(0.91,3.05)\end{array}$ & 8 \\
\hline $\mathrm{LiH}$ & 2019 & China & Osteosarcoma & 36 & Median & qRT-PCR & OS/RFS & Indirectly & $\begin{array}{l}\text { OS:0.53(0.14,2.00) } \\
\text { RFS:0.56(0.14,2.29) }\end{array}$ & 7 \\
\hline Wu D & 2020 & China & NSCLC & 56 & Median & qRT-PCR & OS & Indirectly & $2.861(1.439-5.686)$ & 8 \\
\hline $\begin{array}{l}\text { Chen } \\
\text { XH }\end{array}$ & 2020 & China & $\mathrm{CC}$ & 75 & Mean & qRT-PCR & OS & $\mathrm{U} / \mathrm{M}$ & $2.104(1.221-3.626)$ & 8 \\
\hline $\begin{array}{l}\mathrm{Ma} \\
\mathrm{XD}\end{array}$ & 2020 & China & oscc & 82 & Mean & qRT-PCR & OS & Indirectly & $7.24(1.58,33.10)$ & 8 \\
\hline $\begin{array}{l}\text { Dong } \\
\text { XH }\end{array}$ & 2020 & China & $\mathrm{CRC}$ & 90 & Median & qRT-PCR & OS & Indirectly & $1.30(0.44,3.80)$ & 8 \\
\hline Ho JQ & 2020 & China & CCRCC & 118 & Median & qRT-PCR & OS/RFS & Indirectly & $\begin{array}{l}\text { OS: } 2.98(0.52,17.17) \\
\text { RFS: } 2.17(0.65,7.18)\end{array}$ & 8 \\
\hline $\mathrm{Bu} J Y$ & 2018 & China & $\mathrm{GC}$ & 150 & Median & qRT-PCR & OS & Indirectly & $1.97(1.24,3.14)$ & 7 \\
\hline $\begin{array}{l}\text { Zhu } \\
\text { LJ }\end{array}$ & 2020 & China & $\mathrm{OC}$ & 42 & Median & qRT-PCR & os & Indirectly & $1.85(0.65,5.26)$ & 8 \\
\hline $\begin{array}{l}\text { Zhang } \\
\mathrm{H}\end{array}$ & 2019 & China & $\mathrm{PC}$ & 68 & Mean & qRT-PCR & os & Indirectly & $1.83(0.83,4.03)$ & 6 \\
\hline $\begin{array}{l}\text { Shen } \\
\text { MY }\end{array}$ & 2020 & China & CRC & 102 & Mean & qRT-PCR & OS/PFS & Indirectly & $\begin{array}{l}\text { OS: } 2.57(0.98,6.74) \\
\text { PFS: } 3.18(1.20,8.39)\end{array}$ & 7 \\
\hline $\begin{array}{l}\text { Zhang } \\
\text { Q }\end{array}$ & 2020 & China & $\mathrm{HCC}$ & 49 & Mean & qRT-PCR & os & Indirectly & $1.96(0.66,5.84)$ & 7 \\
\hline $\begin{array}{l}\text { Deng } \\
\text { LL }\end{array}$ & 2016 & China & $\mathrm{BC}$ & 195 & Mean & qRT-PCR & OS & $\mathrm{U} / \mathrm{M}$ & $2.27(1.237,4.165)$ & 8 \\
\hline $\begin{array}{l}\text { Han } \\
\text { QL }\end{array}$ & 2019 & China & $\mathrm{HCC}$ & 73 & Median & qRT-PCR & os & Indirectly & $2.02(1.04,3.92)$ & 8 \\
\hline $\begin{array}{l}\text { Zong } \\
\text { MZ }\end{array}$ & 2019 & China & ESCC & 175 & Median & qRT-PCR & OS/DFS & $\mathrm{U} / \mathrm{M}$ & $\begin{array}{l}\text { OS:3.347(1.423,5.457) } \\
\text { DFS:3.568(1.537,5.778) }\end{array}$ & 8 \\
\hline $\begin{array}{l}\text { Note: } \mathrm{HC} \\
\text { non-sme } \\
\text { carcinor } \\
\text { survival }\end{array}$ & $\begin{array}{l}\text { hepa } \\
\text { cell lu } \\
\text {; } \mathrm{BC}: \text { : } \\
\text { M: ur }\end{array}$ & $\begin{array}{l}\text { ellular } \\
\text { cancer; } \\
\text { ast canc } \\
\text { ariate/m }\end{array}$ & $\begin{array}{l}\text { noma; CRC: c } \\
\text { Cervical canc } \\
\text { fC: gastric car } \\
\text { /ariate analys }\end{array}$ & $\begin{array}{l}\text { ectal ac } \\
\text { CRCC: } \\
\text { iESCC: } \\
\text { IOS: Ne }\end{array}$ & $\begin{array}{l}\text { carcino } \\
\text { r cell re } \\
\text { phagea }\end{array}$ & $\begin{array}{l}\text {; oc: ova } \\
\text { cell carci } \\
\text { quamous } \\
\text { Scale }\end{array}$ & $\begin{array}{l}\text { carcinom } \\
\text { na; OSCC: } \\
\text { carcinome }\end{array}$ & $\begin{array}{l}\text { NBC: triple } \\
\text { I squamou } \\
\text { S: overall }\end{array}$ & $\begin{array}{l}\text { gative breast cancer; NS } \\
\text { ll carcinoma; PC: prost } \\
\text { ival; RFS: Recurrence-fr }\end{array}$ & \\
\hline
\end{tabular}

\section{Prognostic value of AWPPH}

A total of 19 studies with 1699 patients were available to evaluate the effects of AWPPH expression on OS in human cancers. As shown in Figure 2 , the pooled results suggested that elevated AWPPH expression predicted a poor OS for cancers $(\mathrm{HR}=1.79,95 \% \mathrm{Cl}$ : $1.44-2.14, \mathrm{P}<0.001)$ with no heterogeneity $(R=0 \%, P=0.737)$ (Figure $2 A)$. Furthermore, subgroup analysis was also performed to explore the association between $\mathrm{HRs}$ and $0 \mathrm{~S}$ 
including cancer type, sample size, HR estimation method, and cut-off value. The results showed that cancer type and sample size influence the prognostic value of AWPPH on OS (Figure 3 and 4), whereas the HE estimation methods and cut-off value have no impact on it (Figure 5 and 6). There was a negatively relationship between AWPPH expression and OS in the patients $\mathrm{HCC}(\mathrm{HR}=2.22,95 \% \mathrm{Cl}$ : 1.05-3.38) and NSCLC (HR=2.01, 95\% Cl: 1.03-2.99), and other cancers ( $\mathrm{HR}=1.79,95 \% \mathrm{Cl}$ : 1.21-2.36) (Figure 3). In addition, the effect of AWPPH overexpression on predicting short OS occurred in the studies with sample size $>70$ (HR=1.99, 95\% Cl: 1.55-2.44) (Figure 4).

\section{Association between AWPPH and clinicopathological features}

The correlation between AWPPH expression and clinicopathological characteristics were examined with OR analysis in 15 studies with 1332 cancer patients (Figure 7). 12 studies with 1143 patients were included to analysis the link between AWPPH and TNM stage, and the pooled data found an obvious association between AWPPH overexpression and advanced TNM stage (OR=2.67, 95\%Cl: 1.86-3.83, $\mathrm{P}<0.001)(\mathrm{Figure} 4 \mathrm{~B})$. The results also showed that overexpression of AWPPH predicts larger tumor size (OR=2.64, 95\%Cl:1.47-4.73, P=0.001, Figure 4D). In addition, 2 studies with 137 patients were included to analyze the link between AWPPH and macro-vascular invasion, the results revealed an obvious association between AWPPH expression and MVI (OR=2.08, 95\% Cl: 1.04-4.16, $\mathrm{P}=0.04$, Figure 4E). As shown in Figure 4F, $491 \mathrm{cancer}$ patients from 5 studies were included to evaluate the correlation between AWPPH and LNM, and the results indicated that the patients with elevated AWPPH expression were more susceptibility to develop LNM (OR=2.68, 95\% Cl: 1.82-3.96, P<0.001).

\section{Publication bias and sensitivity analysis}

To evaluate the publication bias, the Begg's funnel plot and Egger's linear regression tests were applied in this meta-analysis. In the analysis of evaluating the association between AWPPH expression on OS, visual inspection of the Begg's funnel plot did not reveal asymmetry (Figure 2C), and Egger's test also suggested the absence of publication bias $(t=0.06, p=0.953)$. We also detected the heterogeneity through sensitivity analysis, and the pooled HR was not significantly changed after removing each study, suggesting that the results were stable (Figure 2D).

\section{Discussion}

Collective evidence has indicated that IncRNA AWPPH is closely related to cancer. Initially, IncRNA AWPPH was identified as an overexpressed oncogene in hepatocellular carcinoma [11]. Its overexpression is associated with tumor size, clinical stage, and poor prognosis in patients with hepatocellular carcinoma [21]. Currently, IncRNA AWPPH has been confirmed as a dysregulated oncogene in other several malignancies, such as GC [21], CRC [31], NSCLC [12]. Moreover, the silence of AWPPH significantly suppressed cell proliferation, migration, and invasion in a variety of human cancers. It has drawn great attention as carcinogenic IncRNA in many kinds of cancers. Many researchers focused on the clinical potential value in predicting cancer prognosis. However, inconsistency regarding the predictive value of IncRNA AWPPH in some prognostic parameters, e.g., TNM stage, LNM, and DM, arise from a wide range of studies due to heterogeneity.

In the present meta-analysis, we found that patients with elevated AWPPH expression tended to have poorer OS in cancer patients. Namely, high IncRNA AWPPH expression may serve as an independent predictive factor for the prognosis of cancer patients. Meanwhile, this study also revealed that AWPPH overexpression significantly associated with more advanced TNM stage, higher risk of LNM and MVI, and bigger tumor size. To sum up, our finding suggested that IncRNA could serve as a potential independent prognostic factor for predicting clinical outcomes for cancer patients. However, the underlying molecular mechanism of aberrant AWPPH expression correlated with poor clinical prognosis remains elusive.

Many studies have investigated the functional mechanism of IncRNA AWPPH on tumorigenesis and tumor progression in various cancers (Fig. 8). Previous stduy reported that AWPPH regulates cell proliferation and cell cycle via modulating MDM2/p53 signaling in ESCC [32]. AWPPH acted/functioned as an oncogene to interact with YBX1 to activate the expression of SNAIL1 and PI3K/AKT pathway in the HCC [32]. Wnt/ $\beta$ catenin signal pathway has been revealed to be involved in the regulation of cell proliferation, migration, and invasion in certain cancers [33, 34]. It was reported that IncRNA AWPPH could promote the proliferation, migration, and invasion of breast cancer, ovarian carcinoma, and NSCLC by activating the Wnt/ $\beta$-catenin signal pathway [12, 29, 35]. Moreover, several important pathways were conformed to be modulated by AWPPH in cancers, including MDM2-p53 pathway esophageal squamous cell carcinoma [32], and MEK/ERK pathway in HCC [21]. Furthermore, AWPPH could inhibit colon cancer cell proliferation by downregulating GLUT-1 [36] and cancers by upregulating TGF- $\beta 1$ [28, 37, 38]. Liu et al. demonstrated that AWPPH contributes to cisplatin resistance by inducing the expression of CDK1 and GTSE5 (cell cycle-associated factors), and suppressed the expression of CCNC and BIRC5 (cell apoptosis-associated factors), providing a brand new insight for the cisplatin resistance of gastric cancer NSCLC [39].

In addition, growing evidence has demonstrated that AWPPH functions as competitive endogenous RNA (ceRNA) to regulate miRNAs, and plays a key role in the initiation, development, and chemoresistance of cancer. In gastric cancer, Bu et al. demonstrated that AWPPH promotes cell proliferation and tumorigenesis by regulating miR-497/NTRK3 axis [22]. Recently, miR-128-3p was found to be a target of AWPPH in ovarian cancer by Zhu et al. [13]. In NSCLC, Wu et al. also demonstrated that AWPPH could function as an oncogenic IncRNA by regulating miR-204/CDK6 axis [25]. Furthermore, AWPPH functioned as a ceRNA to promote malignant progression of human cancers through competitive sponging of miR93-3p in osteosarcoma [27], miR-802 in melanoma [40], miR-206 in CRC [17], miR-1224-5p in glioblastoma [41], and miR-513a-5p in CCRCC [42].

Page 5/16 
Several limitations existed in this meta-analysis owing to the discrete data across these clinical studies. First, all included studies were performed in China, which might limit the applicability of our results for other ethnic population. Second, the cut-off values are different among the included articles. Third, some of the HRs were calculated by reconstructing survival curves, which might result in a calculation bias. Finally, only studies published in English or Chinese were obtained in this meta-analysis, and the data collection may be incomplete.

\section{Conclusion}

In conclusion, this meta-analysis demonstrated that AWPPH overexpression was significantly correlated with poorer overall survival in patients with human cancers, and related to advanced TNM stage, higher risk of LNM and MVI, and bigger tumor size. Thus, IncRNA AWPPH might serve as a novel effective prognostic biomarker in cancer patients. Further high-quality studies are required to explore the role of AWPPH in cancers and support this study.

\section{Abbreviations}

AWPPH: Long noncoding RNA associated with poor prognosis of hepatocellular carcinoma, ORs: odds ratios, OS: overall survival , NOS: Newcastle-Ottawa Scale , HCC: hepatocellular carcinoma, CRC: colorectal adenocarcinoma, OC: ovarian carcinoma, TNBC: triple-negative breast cancer, NSCLC: non-small cell lung cancer, CC: cervical cancer, OSCC: oral squamous cell carcinom, CCRCC: clear cell renal cell carcinoma, GC:

gastric cancer, PC: prostate carcinoma, BC:breast cancer, ESCC: esophageal squamous cell carcinoma, qRT-PCR: quantitative real-time polymerase chain reaction, LNM:lymph node metastasis, MVI: macro-vascular invasion , DM: distant metastasis, ceRNA: competitive endogenous RNA

\section{Declarations}

\section{Ethics approval and consent to participate}

Not applicable.

\section{Consent for publication}

Not applicable.

\section{Availability of data and materials}

All data analyzed during this study are included in this published article.

\section{Competing interests}

The authors declare that they have no competing interests.

\section{Funding}

This work was supported by the Natural Science Foundation of Zhejiang Province (No. LY13H160029), the Natural Science Foundation of Zhejiang Province (No. LQ17H160013), and the Zhejiang Province Health Department Foundation (2018ky284) participated by YFL. YFL not only conceived and designed this study, but also read and approved the final manuscript. The funding bodies had no influences on the design of the study and collection, analysis, and interpretation of data and in writing the manuscript.

\section{Authors' contributions}

Conceived and designed the experiments: YFL and DBC. Performed the experiments: XMR, HJX and DBC. Analyzed the data: HJX. Contributed analysis tools/materials: XMR and HJY. Wrote the paper: YFL, XLM. All authors have read and approved the final manuscript.

\section{Acknowledgements}

We are grateful to all researchers of enrolled studies.

\section{Conflict of interest}

The authors have declared that no competing interest exists.

\section{References}

1. Chen W, Zheng R, Baade PD, et al. Cancer statistics in China, 2015. CA Cancer J Clin. 2016; 2(66): 115-132. 
2. Arenz A, Patze J, Kornmann E, et al. HPV-negative and HPV-positive HNSCC cell lines show similar numerical but different structural chromosomal aberrations. Head Neck. 2019;

3. Helleux A, Debien V, Fadloun A, et al. [Epigenetic alterations in kidney cancers]. Bull Cancer. 2019;

4. Johansson PA, Nathan V, Bourke LM, et al. Evaluation of the contribution of germline variants in BRCA1 and BRCA2 to uveal and cutaneous melanoma. Melanoma Res. 2019; 5(29): 483-490.

5. Chen Y, Wang J, Fan Y, et al. Absence of the long noncoding RNA H19 results in aberrant ovarian STAR and progesterone production. Mol Cell Endocrinol. 2019; 490): 15-20.

6. Fico A, Fiorenzano A, Pascale E, Patriarca EJ, Minchiotti G. Long non-coding RNA in stem cell pluripotency and lineage commitment: functions and evolutionary conservation. Cell Mol Life Sci. 2019; 8(76): 1459-1471.

7. Porto FW, Daulatabad SV, Janga SC. Long Non-Coding RNA Expression Levels Modulate Cell-Type-Specific Splicing Patterns by Altering Their Interaction Landscape with RNA-Binding Proteins. Genes (Basel). 2019; 8(10):

8. Tang Y, Wang J, Lian Y, et al. Linking long non-coding RNAs and SWI/SNF complexes to chromatin remodeling in cancer. Mol Cancer. 2017; 1(16): 42.

9. Cui RJ, Fan JL, Lin YC, et al. miR-124-3p availability is antagonized by LncRNA-MALAT1 for Slug-induced tumor metastasis in hepatocellular carcinoma. Cancer Med. 2019;

10. Xu Y, Deng J, Wang G, Zhu Y. Long Non-coding RNAs in Prostate Cancer: Functional Roles and Clinical Implications. Cancer Lett. 2019;

11. Zhao X, Liu Y, Yu S. Long noncoding RNA AWPPH promotes hepatocellular carcinoma progression through YBX1 and serves as a prognostic biomarker. Bba-Mol Basis Dis. 2017; 7(1863): 1805-1816.

12. Song Z, Du J, Zhou L, Sun B. IncRNA AWPPH promotes proliferation and inhibits apoptosis of non-small cell lung cancer cells by activating the Wnt/-catenin signaling pathway. Mol Med Rep. 2019; 5(19): 4425-4432.

13. Zhu L, Wang A, Gao M, Duan X, Li Z. LncRNA MIR4435-2HG triggers ovarian cancer progression by regulating miR-128-3p/CKD14 axis. Cancer Cell Int. 2020; 1451(20):

14. Tierney JF, Stewart LA, Ghersi D, Burdett S, Sydes MR. Practical methods for incorporating summary time-to-event data into meta-analysis. 2007; 1(8): 16.

15. Han QL, Chen BT, Zhang KJ, Xia ST, Zhong WW, Zhao ZM. The long non-coding RNA AK001796 contributes to poor prognosis and tumor progression in hepatocellular carcinoma. Eur Rev Med Pharmacol Sci. 2019; 5(23): 2013-2019.

16. Zong MZ, Shao Q, An XS. Expression and prognostic significance of long noncoding RNA AK001796 in esophageal squamous cell carcinoma. Eur Rev Med Pharmacol Sci. 2019; 1(23): 181-186.

17. Dong X, Yang Z, Yang H, Li D, Qiu X. Long Non-coding RNA MIR4435-2HG Promotes Colorectal Cancer Proliferation and Metastasis Through miR-206/YAP1 Axis. Front Oncol. 2020; 160(10):

18. Ma X, Sheng M. Prognostic value of serum MIR4435-2HG in oral squamous cell carcinoma. Chinese Journal of Stomatology. 2020; $1002-$ 0098(2020)55:1<15:XQM2ZK>2.0.TX;2-M1(55): 15-19.

19. Shen MY, Zhou GR, Y ZZ. LncRNA MIR4435-2HG contributes into colorectal cancer development and predicts poor prognosis. Eur Rev Med Pharmacol Sci. 2020; 4(24): 1771-1777.

20. Wu K, Hu L, Lv X, et al. Long non-coding RNA MIR4435-1HG promotes cancer growth in clear cell renal cell carcinoma. Cancer biomarkers : section A of Disease markers. 2020; 1(29): 39-50.

21. Zhang Q, Cheng S, Cao L, Yang J, Wang Y, Chen Y. LINC00978 promotes hepatocellular carcinoma carcinogenesis partly via activating the MAPK/ERK pathway. Bioscience Rep. 2020; BSR201927903(40):

22. Bu J, Lv W, Liao Y, Xiao X, Lv B. Long non-coding RNA LINC00978 promotes cell proliferation and tumorigenesis via regulating microRNA497/NTRK3 axis in gastric cancer. Int J Biol Macromol. 2019; 123): 1106-1114.

23. Zhang $\mathrm{H}$, Meng $\mathrm{H}$, Huang $\mathrm{X}$, et al. IncRNA MIR4435-2HG promotes cancer cell migration and invasion in prostate carcinoma by upregulating TGF-beta 1. Oncol Lett. 2019; 4(18): 4016-4021.

24. Deng L, Chi Y, Liu L, Huang N, Wang L, Wu J. LINC00978 predicts poor prognosis in breast cancer patients. Sci Rep-Uk. 2016; 37936(6):

25. Wu D, Qin BY, Qi XG, Hong LL, Zhong HB, Huang JY. LncRNA AWPPH accelerates the progression of non-small cell lung cancer by sponging miRNA-204 to upregulate CDK6. Eur Rev Med Pharmaco. 2020; 8(24): 4281-4287.

26. Chen X, Qu J, Yao L, Chen X. Expression and clinicopathological significance of IncRNA AWPPH and miR-203a in cervical cancer[In Chinese]. Journal of Clinical and Experimental Pathology. 2020; 09(1052-1057.

27. Li C, Wang F, Wei B, Wang L, Kong D. LncRNA AWPPH promotes osteosarcoma progression via activation of Wnt/ $\beta$-catenin pathway through modulating miR-93-3p/FZD7 axis. Biochem Biophys Res Commun. 2019; 3(514): 1017-1022.

28. Liu C, Han B, Xin J, Yang C. LncRNA-AWPPH activates TGF- $\beta 1$ in colorectal adenocarcinoma. Oncol Lett. 2019; 5(18): 4719-4725. 
29. Yu G, Wang W, Deng J, Dong S. LncRNA AWPPH promotes the proliferation, migration and invasion of ovarian carcinoma cells via activation of the Wnt/-catenin signaling pathway. Mol Med Rep. 2019; 5(19): 3615-3621.

30. Wang K, Li X, Song C, Li M. LncRNA AWPPH promotes the growth of triple-negative breast cancer by up-regulating frizzled homolog 7 (FZD7). Bioscience Rep. 2018; BSR201812236(38):

31. Liu C, Han B, Xin J, Yang C. LncRNA-AWPPH activates TGF- $\beta 1$ in colorectal adenocarcinoma. Oncol Lett. 2019; 5(18): $4719-4725$.

32. Liu B, Pan CF, Yao GL, Wei K, Xia Y, Chen YJ. The long non-coding RNA AK001796 contributes to tumor growth via regulating expression of p53 in esophageal squamous cell carcinoma. Cancer Cell Int. 2018; 18): 38.

33. Hseu YC, Lin YC, Rajendran P, et al. Antrodia salmonea suppresses invasion and metastasis in triple-negative breast cancer cells by reversing EMT through the NF-kappaB and Wnt/beta-catenin signaling pathway. Food Chem Toxicol. 2019; 124): $219-230$.

34. Liu M, Sun X, Shi S. MORC2 Enhances Tumor Growth by Promoting Angiogenesis and Tumor-Associated Macrophage Recruitment via Wnt/beta-Catenin in Lung Cancer. Cell Physiol Biochem. 2018; 4(51): 1679-1694.

35. Xiu D, Liu G, Yu S, et al. Long non-coding RNA LINC00968 attenuates drug resistance of breast cancer cells through inhibiting the Wnt2/catenin signaling pathway by regulating WNT2. J Exp Clin Canc Res. 2019; 94(38):

36. Bai J, Xu J, Zhao J, Zhang R. Downregulation of IncRNA AWPPH inhibits colon cancer cell proliferation by downregulating GLUT-1. Oncol Lett. 2019; 2(18): 2007-2012.

37. Yanxia H, Aimin L, Zhihua W. LncRNA AWPPH participates in the metastasis of non-small cell lung cancer by upregulating TGF- $\beta 1$ expression. Oncol Lett. 2019; 4(18):

38. Tang L, Wang T, Zhang Y, et al. Long Non-Coding RNA AWPPH Promotes Postoperative Distant Recurrence in Resected Non-Small Cell Lung Cancer by Upregulating Transforming Growth Factor beta 1 (TGF-B1). Med Sci Monit. 2019; 25): 2535-2541.

39. Liu B, Pan C, Ma T, et al. Long non-coding RNA AK001796 contributes to cisplatin resistance of non-small cell lung cancer. Mol Med Rep. 2017; 4(16): 4107-4112.

40. Ma D, Sun D, Wang J, Jin D, Li Y, Han Y. Long non-coding RNA MIR4435-2HG recruits miR-802 from FLOT2 to promote melanoma progression. Eur Rev Med Pharmaco. 2020; 5(24): 2616-2624.

41. Xu H, Zhang B, Yang Y, et al. LncRNA MIR4435-2HG potentiates the proliferation and invasion of glioblastoma cells via modulating miR-12245p/TGFBR2 axis. J Cell Mol Med. 2020; 11(24): 6362-6372.

42. Zhu K, Miao C, Tian Y, et al. IncRNA MIR4435-2HG promoted clear cell renal cell carcinoma malignant progression via miR-513a-5p/KLF6 axis. J Cell Mol Med. 2020; 17(24): 10013-10026.

\section{Figures}

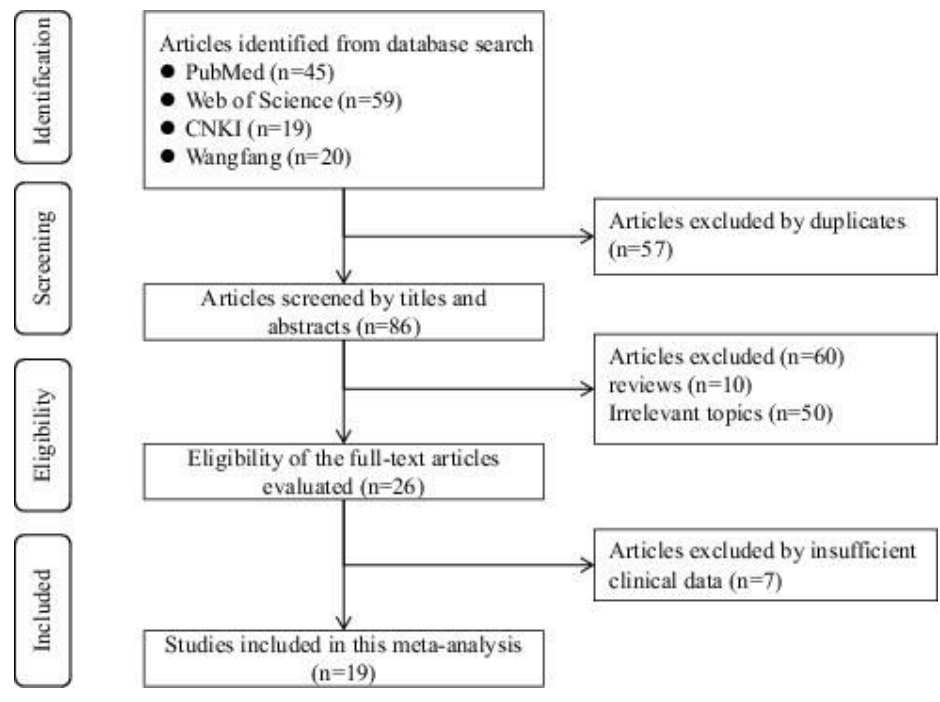

Figure 1

Flow chart of literature search 


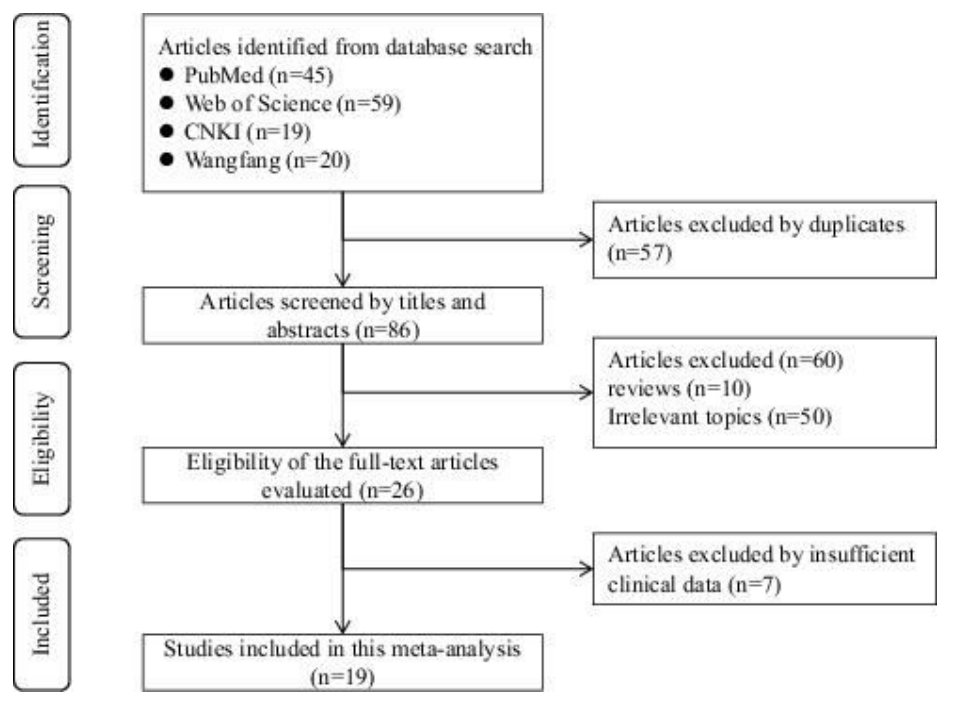

\section{Figure 1}

Flow chart of literature search

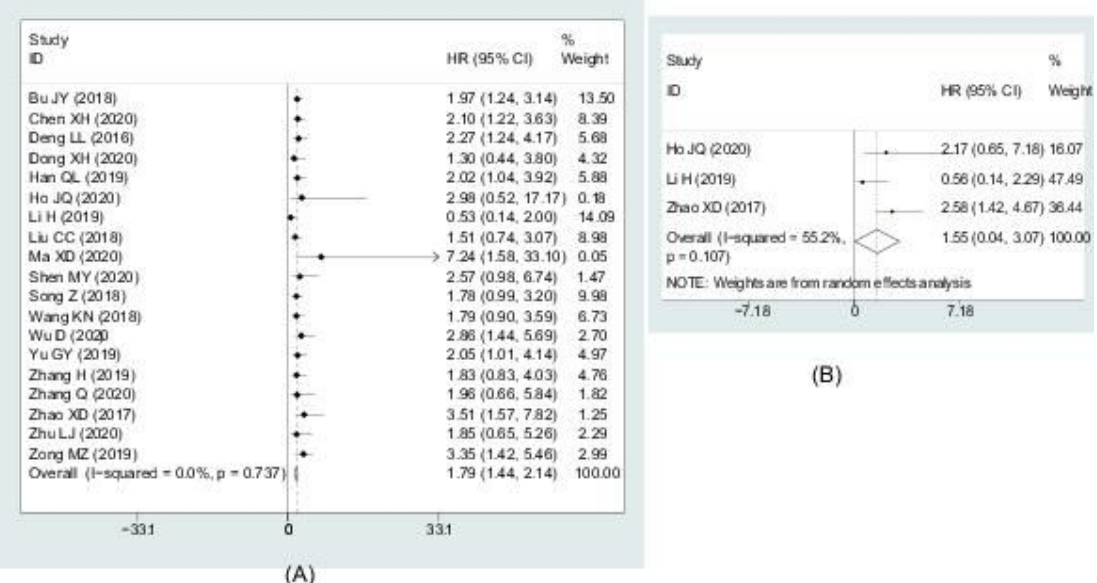

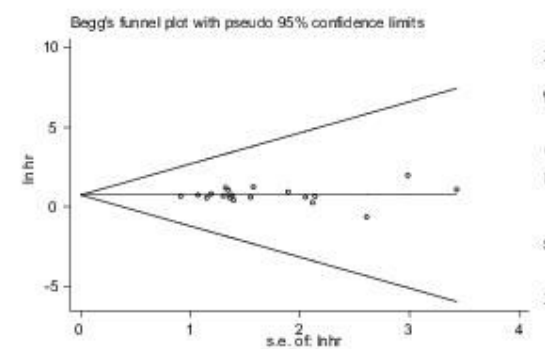

(C)

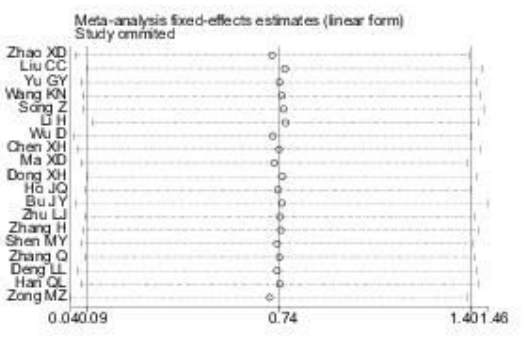

(D)

Figure 2

$(A, B)$ Forest plot and of studies evaluating the association between AWPPH expression and OS and RFS. (C) Begg's publication bias plots of OS, and (D) sensitivity analysis for OS. 


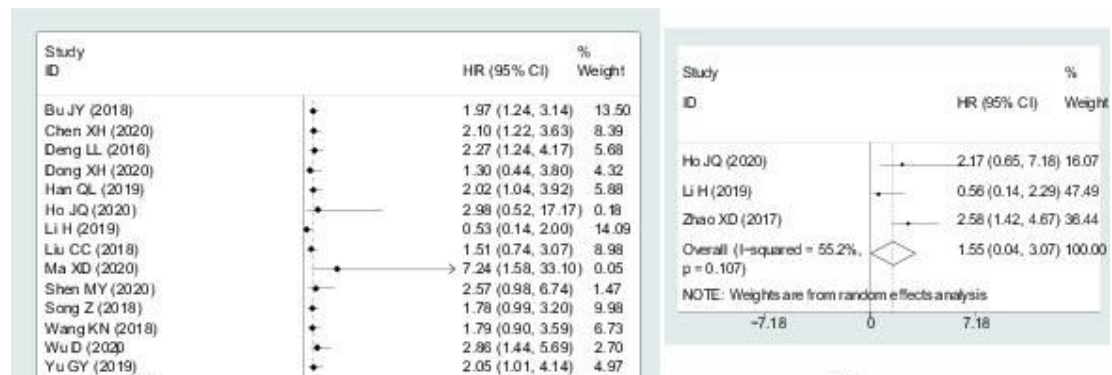

(B)$$
\begin{aligned}
& \text { WuD }\{2020 \\
& \text { Yu GY }\{2019\}
\end{aligned}
$$

Zhang $\mathrm{H}(2019$

Zhang $Q$ (2020)

Zhas $x \mathrm{D}(2017)$

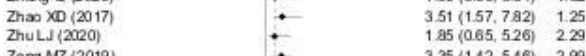

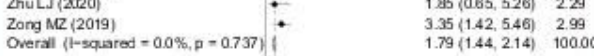

$-331$

(A)

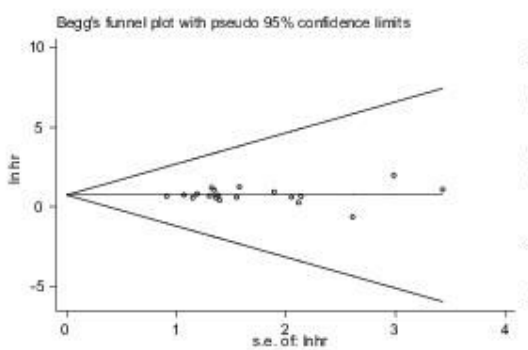

(C)

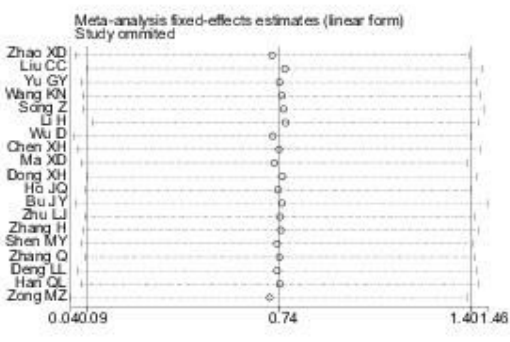

(D)

\section{Figure 2}

$(A, B)$ Forest plot and of studies evaluating the association between AWPPH expression and OS and RFS. (C) Begg's publication bias plots of OS, and (D) sensitivity analysis for OS.

\begin{tabular}{|c|c|c|c|}
\hline $\begin{array}{l}\text { Study } \\
\text { ID }\end{array}$ & & $\mathrm{HR}(95 \% \mathrm{Cl})$ & $\begin{array}{l}\% \\
\text { Weight }\end{array}$ \\
\hline $\begin{array}{l}\text { HCC } \\
\text { Han QL (2019) } \\
\text { Zhang Q (2020) } \\
\text { Zhao XD (2017) } \\
\text { Subtotal (l-squared }=0.0 \%, p=0.681)\end{array}$ & 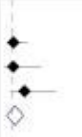 & $\begin{array}{l}2.02(1.04,3.92) \\
1.96(0.66,5.84) \\
3.51(1.57,7.82) \\
2.22(1.05,3.38)\end{array}$ & $\begin{array}{l}5.88 \\
1.82 \\
1.25 \\
8.94\end{array}$ \\
\hline $\begin{array}{l}\text { CRC } \\
\text { Dong XH (2020) } \\
\text { Liu CC }(2018) \\
\text { Shen MY (2020) } \\
\text { Subtotal (1-squared }=0.0 \%, p=0.752 \text { ) }\end{array}$ & $\div$ & $\begin{array}{l}1.30(0.44,3.80) \\
1.51(0.74,3.07) \\
2.57(0.98,6.74) \\
1.55(0.65,2.46)\end{array}$ & $\begin{array}{l}4.32 \\
8.98 \\
1.47 \\
14.76\end{array}$ \\
\hline $\begin{array}{l}\text { OC } \\
\text { Yu GY }(2019) \\
\text { Zhu LJ }(2020) \\
\text { Subtotal }(1-\text { squared }=0.0 \%, p=0.888)\end{array}$ & $\dot{-}$ & $\begin{array}{l}2.05(1.01,4.14) \\
1.85(0.65,5.26) \\
1.99(0.69,3.28)\end{array}$ & $\begin{array}{l}4.97 \\
2.29 \\
7.27\end{array}$ \\
\hline $\begin{array}{l}\text { OTHER } \\
\text { Bu JY (2018) } \\
\text { Chen XH }(2020) \\
\text { Deng LL (2016) } \\
\text { Ho JQ (2020) } \\
\text { Li H (2019) } \\
\text { Ma XD (2020) } \\
\text { Wang KN }(2018) \\
\text { Zhang H (2019) } \\
\text { Zong MZ (2019) } \\
\text { Subtotal (l-squared }=24.3 \%, p=0.228 \text { ) }\end{array}$ & $\div$ & $\begin{array}{l}1.97(1.24,3.14) \\
2.10(1.22,3.63) \\
2.27(1.24,4.17) \\
2.98(0.52,17.17 \\
0.53(0.14,2.00) \\
7.24(1.58,33.10) \\
1.79(0.90,3.59) \\
1.83(0.83,4.03) \\
3.35(1.42,5.46) \\
1.79(1.21,2.36)\end{array}$ & $\begin{array}{l}13.50 \\
8.39 \\
5.68 \\
10.18 \\
14.09 \\
0.06 \\
6.73 \\
4.76 \\
2.99 \\
56.36\end{array}$ \\
\hline $\begin{array}{l}\text { NSCLC } \\
\text { Song Z (2018) } \\
\text { Wu D }(2020) \\
\text { Subtotal }(1 \text {-squared }=0.0 \%, p=0.377 \text { ) }\end{array}$ & 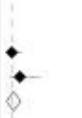 & $\begin{array}{l}1.78(0.99,3.20 \\
2.86(1.44,5.69) \\
2.01(1.03,2.99)\end{array}$ & $\begin{array}{l}9.98 \\
2.70 \\
12.68\end{array}$ \\
\hline Overall $(1-$ squared $=0.0 \%, p=0.737)$ & 0 & $1.79(1.44,2.14)$ & 100.00 \\
\hline
\end{tabular}

$-33.1$

0

33.1

Figure 3

Forest plots of subgroup analysis for the HRs of OS by tumor type. 


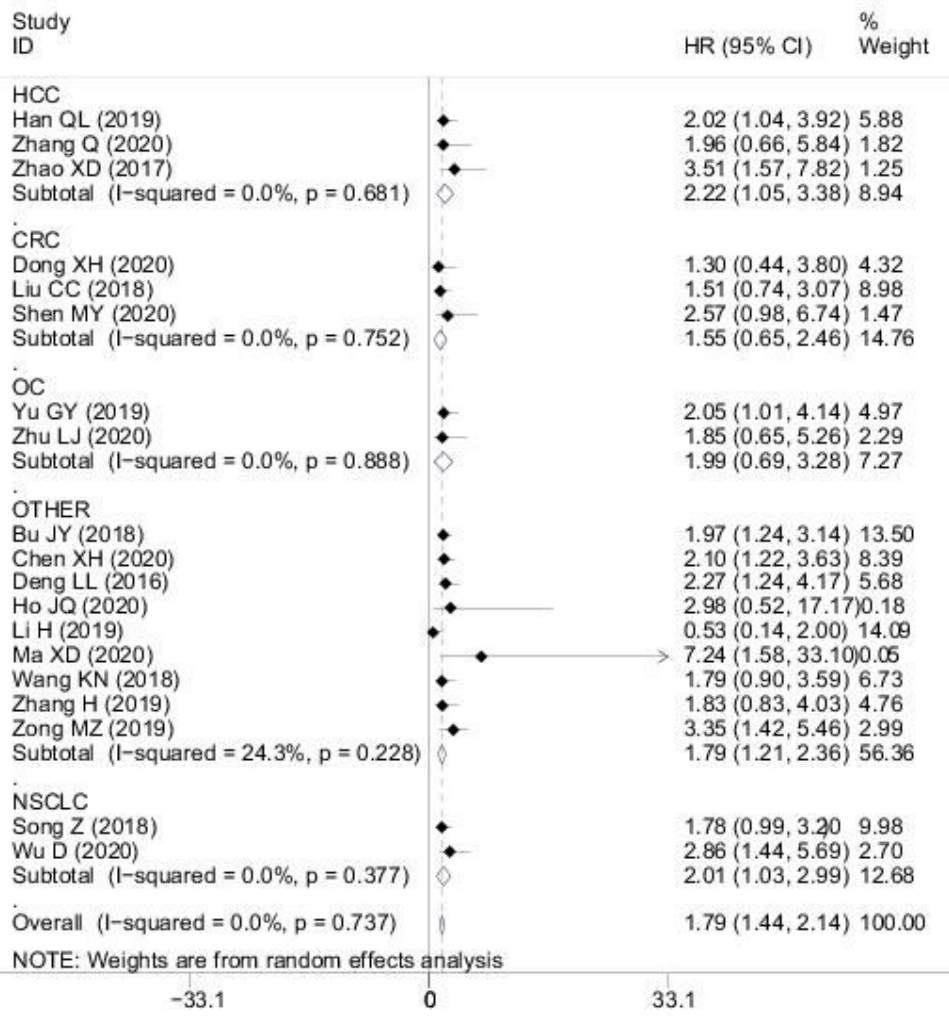

\section{Figure 3}

Forest plots of subgroup analysis for the HRs of OS by tumor type.

\begin{tabular}{|c|c|c|c|}
\hline $\begin{array}{l}\text { Study } \\
\text { ID }\end{array}$ & & $\mathrm{HR}(95 \% \mathrm{Cl})$ & $\begin{array}{l}\% \\
\text { Weight }\end{array}$ \\
\hline$>70$ & & & \\
\hline Bu JY (2018) & $\bullet$ & $1.97(1.24,3.14)$ & 13.50 \\
\hline Chen XH (2020) & $\bullet$ & 2. $10(1.22,3.63)$ & 8.39 \\
\hline Deng LL (2016) & $\bullet$ & $2.27(1.24,4.17)$ & 5.68 \\
\hline Dong XH (2020 & $\bullet$ & $1.30(0.44,3.80)$ & 4.32 \\
\hline Han QL (2019) & $\bullet$ & $2.02(1.04,3.92)$ & 5.88 \\
\hline Ho JQ (2020) & $\bullet$ & $2.98(0.52,17.17)$ & 0.18 \\
\hline Liu CC (2018) & $\bullet$ & $1.51(0.74,3.07)$ & 8.98 \\
\hline $\operatorname{Ma}$ XD (2020) & $\longrightarrow$ & $7.24(1.58,33.10)$ & 0.05 \\
\hline Shen MY (2020) & $\bullet$ & $2.57(0.98,6.74)$ & 1.47 \\
\hline Song Z (2018) & 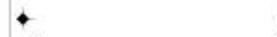 & $1.78(0.99,3.20)$ & 9.98 \\
\hline Zhao XD (2017) & $\bullet$ & $3.51(1.57,7.82)$ & 1.25 \\
\hline Zong MZ (2019) & $\bullet$ & $3.35(1.42,5.46)$ & 2.99 \\
\hline Subtotal $(1-$ squared $=0.0 \%, p=0.936)$ & 1 & $1.99(1.55,2.44)$ & 62.64 \\
\hline . & i & & \\
\hline$\leq 70$ & 1 & & \\
\hline Li H (2019) & $\bullet$ & $0.53(0.14,2.00)$ & 14.09 \\
\hline Wang KN (2018) & $\bullet$ & $1.79(0.90,3.59)$ & 6.73 \\
\hline Wu D $(2020)$ & $\bullet$ & $2.86(1.44,5.69)$ & 2.70 \\
\hline Yu GY (2019) & $\bullet$ & $2.05(1.01,4.14)$ & 4.97 \\
\hline Zhang $\mathrm{H}$ (2019) & $\bullet$ & $1.83(0.83,4.03)$ & 4.76 \\
\hline Zhang Q (2020) & $\bullet$ & $1.96(0.66,5.84)$ & 1.82 \\
\hline Zhu LJ (2020) & $\bullet$ & $1.85(0.65,5.26)$ & 2.29 \\
\hline Subtotal $(1-$ squared $=11.0 \%, p=0.345)$ & 0 & $1.51(0.89,2.14)$ & 37.36 \\
\hline . & & & \\
\hline Overall $(1-$ squared $=0.0 \%, p=0.737)$ & 1 & $1.79(1.44,2.14)$ & 100.00 \\
\hline NOTE: Weights are from random effects & alysis & & \\
\hline-33.1 & 33. & & \\
\hline
\end{tabular}

\section{Figure 4}

Forest plots of subgroup analysis for the HRs of OS by sample size. 


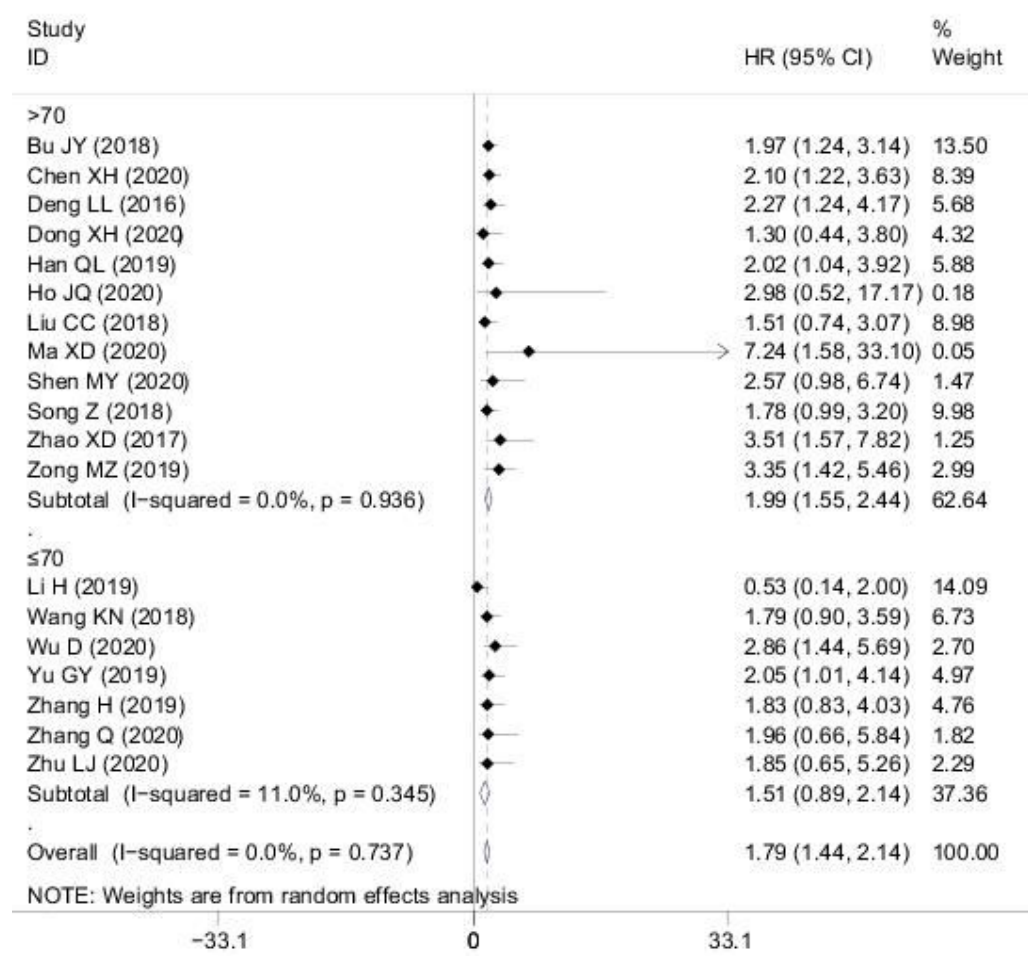

\section{Figure 4}

Forest plots of subgroup analysis for the HRs of OS by sample size.

\begin{tabular}{|c|c|c|c|}
\hline Study & & & $\%$ \\
\hline ID & & $\operatorname{HR}(95 \% \mathrm{Cl})$ & Weight \\
\hline Median & & & \\
\hline Bu JY (2018) & $\bullet$ & $1.97(1.24,3.14)$ & 13.50 \\
\hline Dong XH (2020) & $\bullet$ & $1.30(0.44,3.80)$ & 4.32 \\
\hline Han QL (2019) & $\bullet$ & $2.02(1.04,3.92)$ & 5.88 \\
\hline Ho JQ (2020) & $\bullet$ & $2.98(0.52,17.17)$ & 0.18 \\
\hline $\mathrm{LiH}(2019)$ & $\bullet$ & $0.53(0.14,2.00)$ & 14.09 \\
\hline Liu CC (2018) & $\bullet$ & $1.51(0.74,3.07)$ & 8.98 \\
\hline Song Z (2018) & - & $1.78(0.99,3.20)$ & 9.98 \\
\hline Wang KN (2018) & $\bullet$ & $1.79(0.90,3.59)$ & 6.73 \\
\hline Wu D (2020) & $\bullet-$ & $2.86(1.44,5.69)$ & 2.70 \\
\hline Yu GY (2019) & $\bullet$ & $2.05(1.01,4.14)$ & 4.97 \\
\hline Zhao XD (2017) & $\bullet$ & $3.51(1.57,7.82)$ & 1.25 \\
\hline Zhu LJ $(2020)$ & 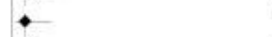 & $1.85(0.65,5.26)$ & 2.29 \\
\hline Zong MZ (2019) & $\bullet$ & $3.35(1.42,5.46)$ & 2.99 \\
\hline Subtotal $(1-$ squared $=1.9 \%, p=0.427)$ & l & $1.70(1.30,2.10)$ & 77.84 \\
\hline o & & & \\
\hline Mean & & & \\
\hline Chen XH (2020) & $\bullet$ & $2.10(1.22,3.63)$ & 8.39 \\
\hline Deng LL (2016) & $\bullet$ & $2.27(1.24,4.17)$ & 5.68 \\
\hline $\operatorname{Ma} X D(2020)$ & $\bullet$ & $7.24(1.58,33.10)$ & 0.05 \\
\hline Shen MY (2020) & $\bullet$ & $2.57(0.98,6.74)$ & 1.47 \\
\hline Zhang $\mathrm{H}(2019)$ & $\bullet$ & $1.83(0.83,4.03)$ & 4.76 \\
\hline Zhang Q (2020) & + & $1.96(0.66,5.84)$ & 1.82 \\
\hline Subtotal $(1$-squared $=0.0 \%, p=0.984)$ & $\diamond$ & $2.12(1.38,2.86)$ & 22.16 \\
\hline . & & & \\
\hline Overall $(1$-squared $=0.0 \%, p=0.737)$ & 1 & $1.79(1.44,2.14)$ & 100.00 \\
\hline
\end{tabular}

$\begin{array}{lll}-33.1 & 0 & 33.1\end{array}$

\section{Figure 5}

Forest plots of subgroup analysis for the HRs of OS by cut-off value. 


\begin{tabular}{|c|c|c|c|}
\hline \multicolumn{2}{|l|}{ Study } & \multirow{3}{*}{$\operatorname{HR}(95 \% \mathrm{Cl})$} & \multirow{2}{*}{$\begin{array}{l}\% \\
\text { Weight }\end{array}$} \\
\hline ID & & & \\
\hline \multicolumn{3}{|l|}{ Median } & \\
\hline Bu JY (2018) & $\bullet$ & $1.97(1.24,3.14)$ & 13.50 \\
\hline Dong XH (2020) & $\bullet$ & $1.30(0.44,3.80)$ & 4.32 \\
\hline Han QL (2019) & $\bullet$ & $2.02(1.04,3.92)$ & 5.88 \\
\hline Ho JQ (2020) & $\bullet$ & $2.98(0.52,17.17)$ & 0.18 \\
\hline $\mathrm{LiH}(2019)$ & $\bullet$ & $0.53(0.14,2.00)$ & 14.00 \\
\hline Liu CC (2018) & $\bullet$ & $1.51(0.74,3.07)$ & 8.98 \\
\hline Song Z (2018) & $\bullet$ & $1.78(0.99,3.20)$ & 9.98 \\
\hline Wang KN (2018) & 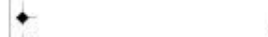 & $1.79(0.90,3.59)$ & 6.73 \\
\hline Wu D $(2020)$ & $\bullet$ & $2.86(1.44,5.69)$ & 2.70 \\
\hline Yu GY (2019) & $\bullet$ & $2.05(1.01,4.14)$ & 4.97 \\
\hline Zhao XD (2017) & $\bullet$ & $3.51(1.57,7.82)$ & 1.25 \\
\hline Zhu LJ (2020) & 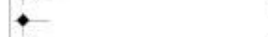 & $1.85(0.65,5.26)$ & 2.29 \\
\hline Zong MZ (2019) & $\bullet$ & $3.35(1.42,5.46)$ & 2.99 \\
\hline Subtotal $(1-$ squared $=1.9 \%, p=0.427)$ & 1 & $1.70(1.30,2.10)$ & 77.84 \\
\hline \multirow{2}{*}{\multicolumn{4}{|c|}{ Mean }} \\
\hline & & & \\
\hline Chen XH (2020) & $\bullet$ & $2.10(1.22,3.63)$ & 8.39 \\
\hline Deng LL (2016) & $\bullet$ & $2.27(1.24,4.17)$ & 5.68 \\
\hline $\operatorname{Ma} X D(2020)$ & $\longrightarrow$ & $7.24(1.58,33.10)$ & 0.05 \\
\hline Shen MY (2020) & $\bullet$ & $2.57(0.98,6.74)$ & 1.47 \\
\hline Zhang H (2019) & $\bullet$ & $1.83(0.83,4.03)$ & 4.76 \\
\hline Zhang Q (2020) & $\bullet$ & $1.96(0.66,5.84)$ & 1.82 \\
\hline Subtotal $(1-$ squared $=0.0 \%, p=0.984)$ & $\theta$ & $2.12(1.38,2.86)$ & 22.16 \\
\hline . & & & \\
\hline Overall $(1$-squared $=0.0 \%, p=0.737)$ & 1 & $1.79(1.44,2.14)$ & 100.00 \\
\hline
\end{tabular}

$\begin{array}{lll}-33.1 & 0 & 33.1\end{array}$

\section{Figure 5}

Forest plots of subgroup analysis for the HRs of OS by cut-off value.

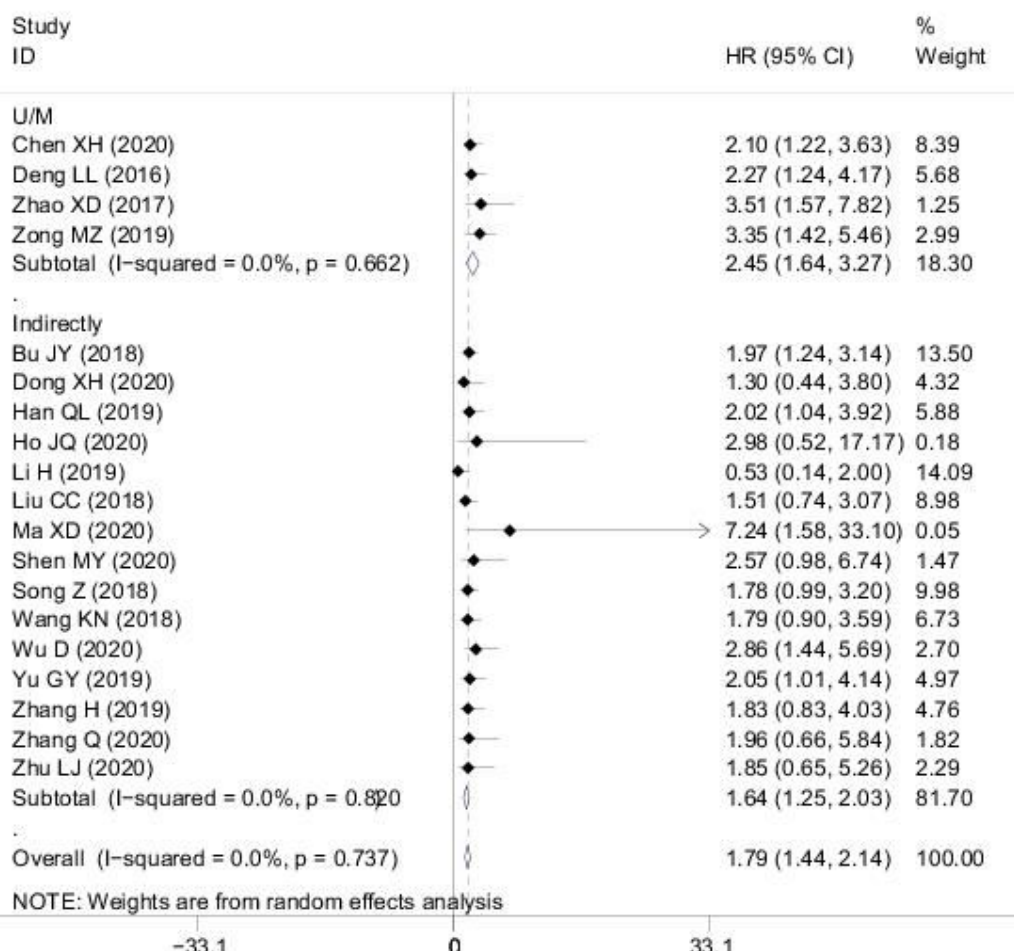

$-33.1$

33.1

\section{Figure 6}

Forest plots of subgroup analysis for the HRs of OS by HR estimation method. 


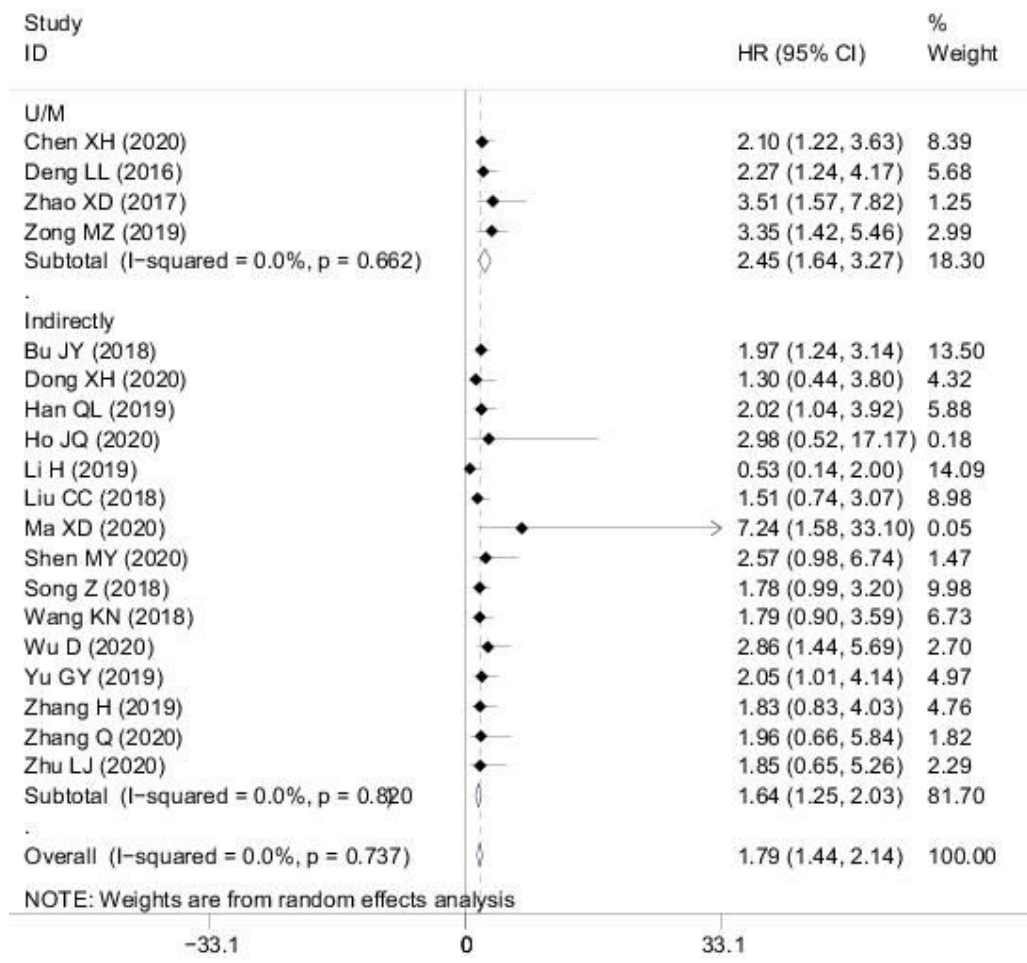

\section{Figure 6}

Forest plots of subgroup analysis for the HRs of OS by HR estimation method.

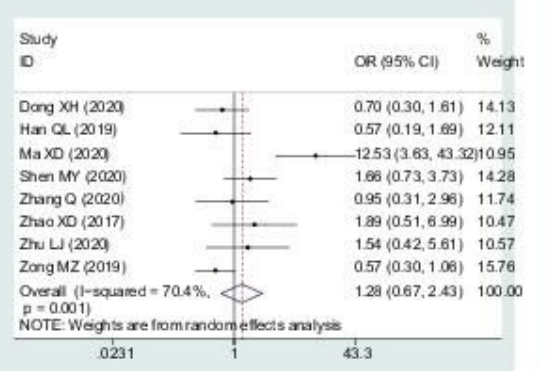

(A)

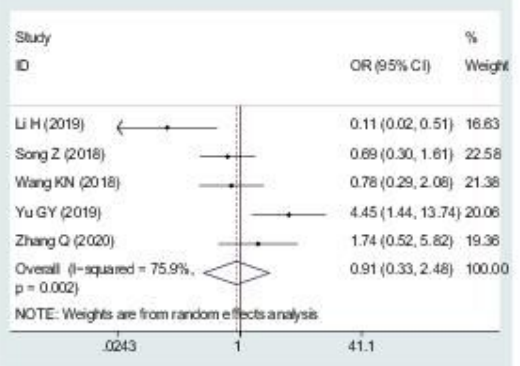

(C)

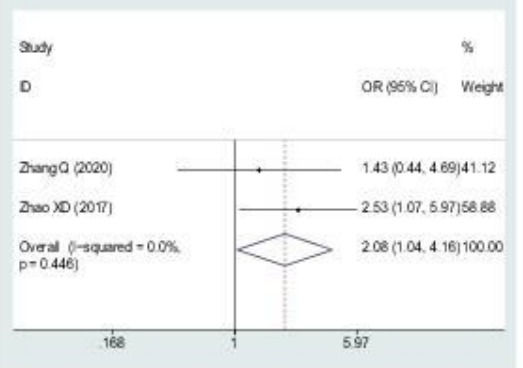

(E)

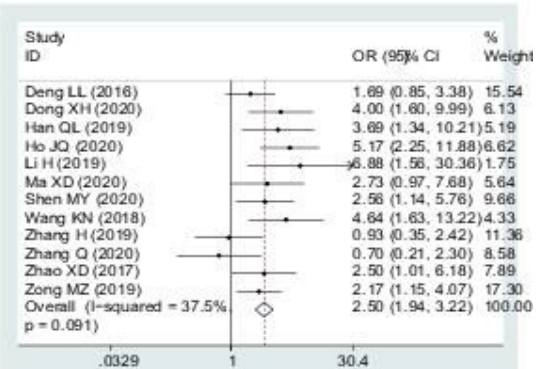

(B)

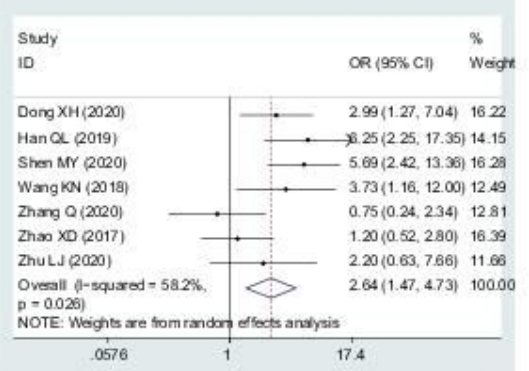

(D)

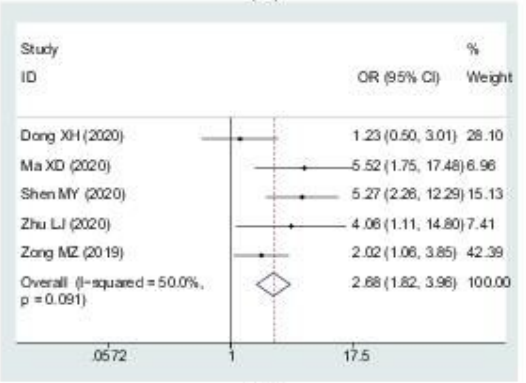

(F)

Figure 7 
Meta-analysis for the association between AWPPH expression with clinicopathological parameters. The investigated clinicopathological parameters are: (A) differentiation status, (B) TNM stage, (C) distant metastasis, (D) tumor size, (E) macro-vascular invasion,and (F) lymph node metastasis.

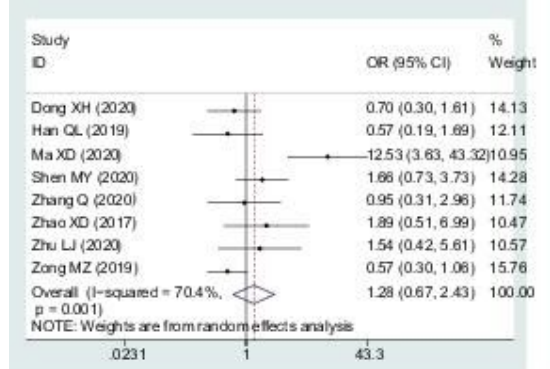

(A)

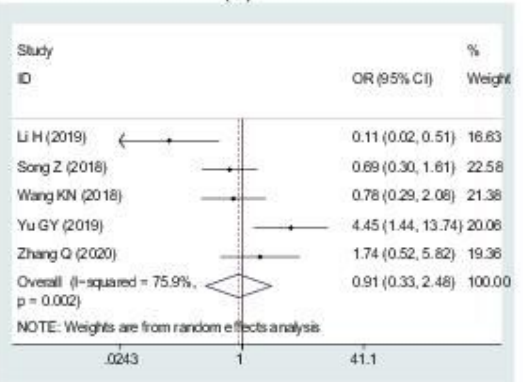

(C)

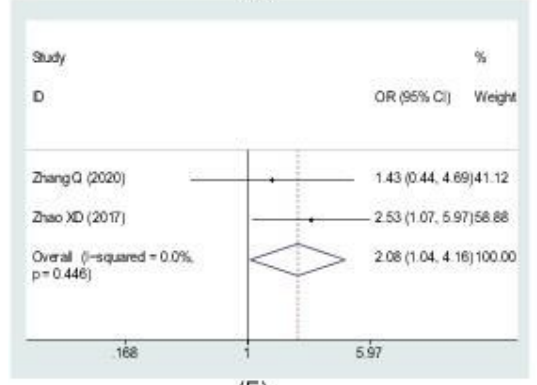

(E)

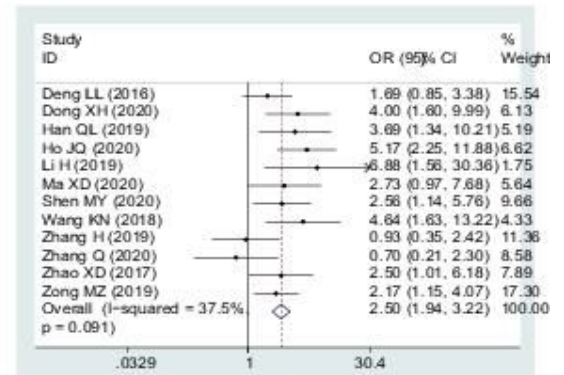

(B)

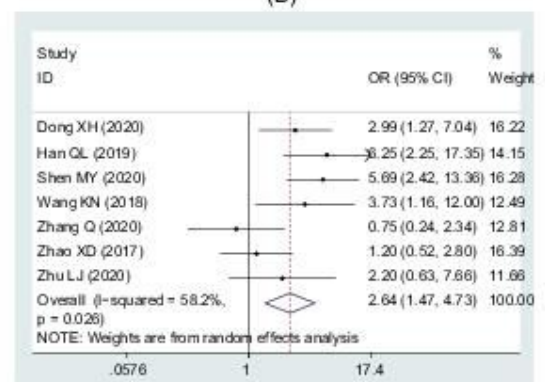

(D)

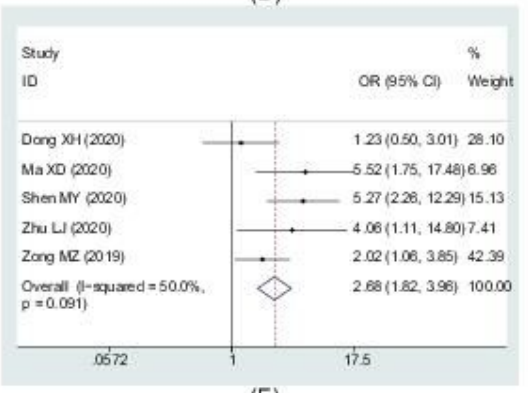

(F)

Figure 7

Meta-analysis for the association between AWPPH expression with clinicopathological parameters. The investigated clinicopathological parameters are: (A) differentiation status, (B) TNM stage, (C) distant metastasis, (D) tumor size, (E) macro-vascular invasion,and (F) lymph node metastasis.

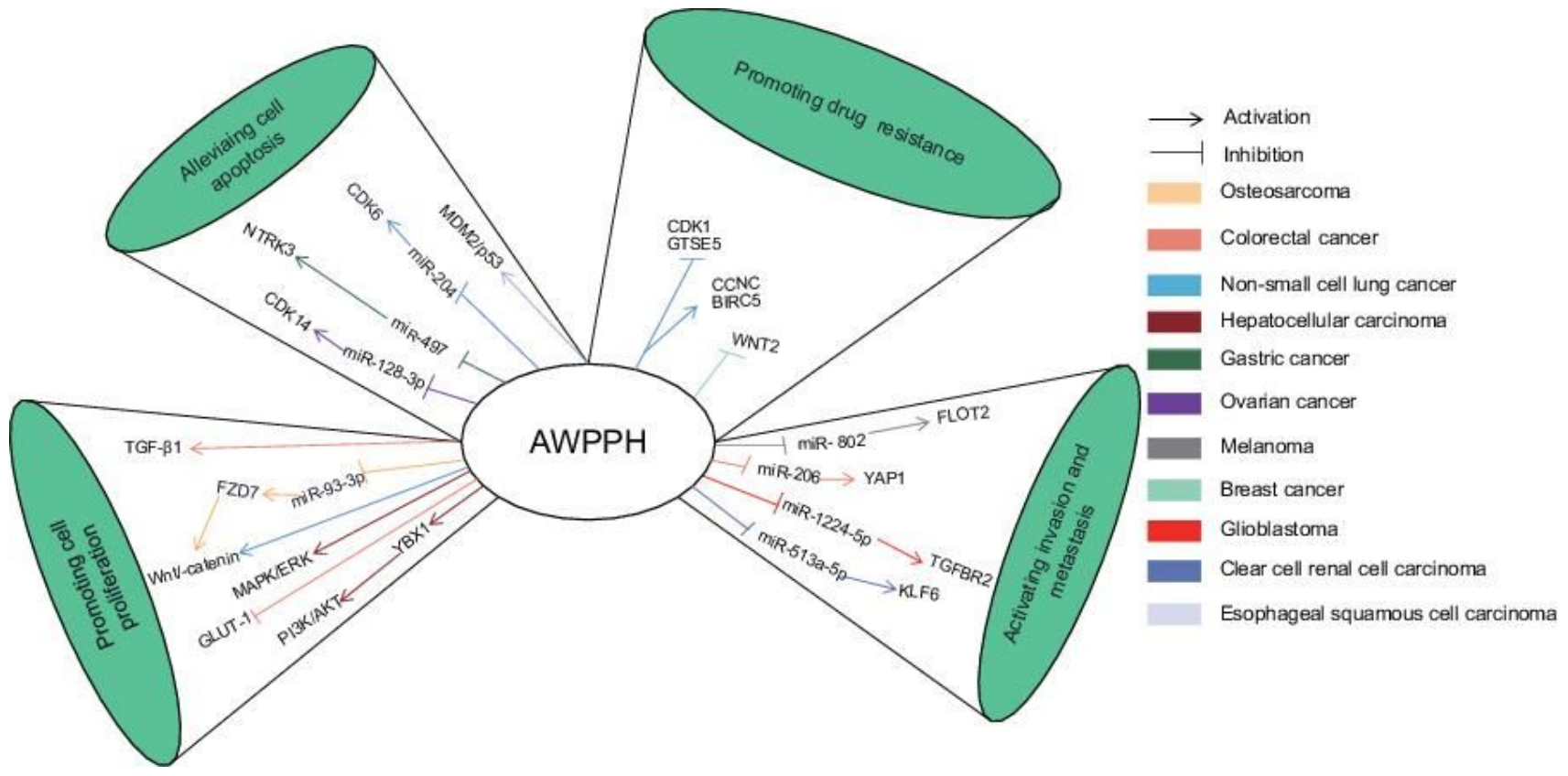

Figure 8 
Schematic diagrams of various molecules and signaling pathways associated with AWPPH in human cancers.

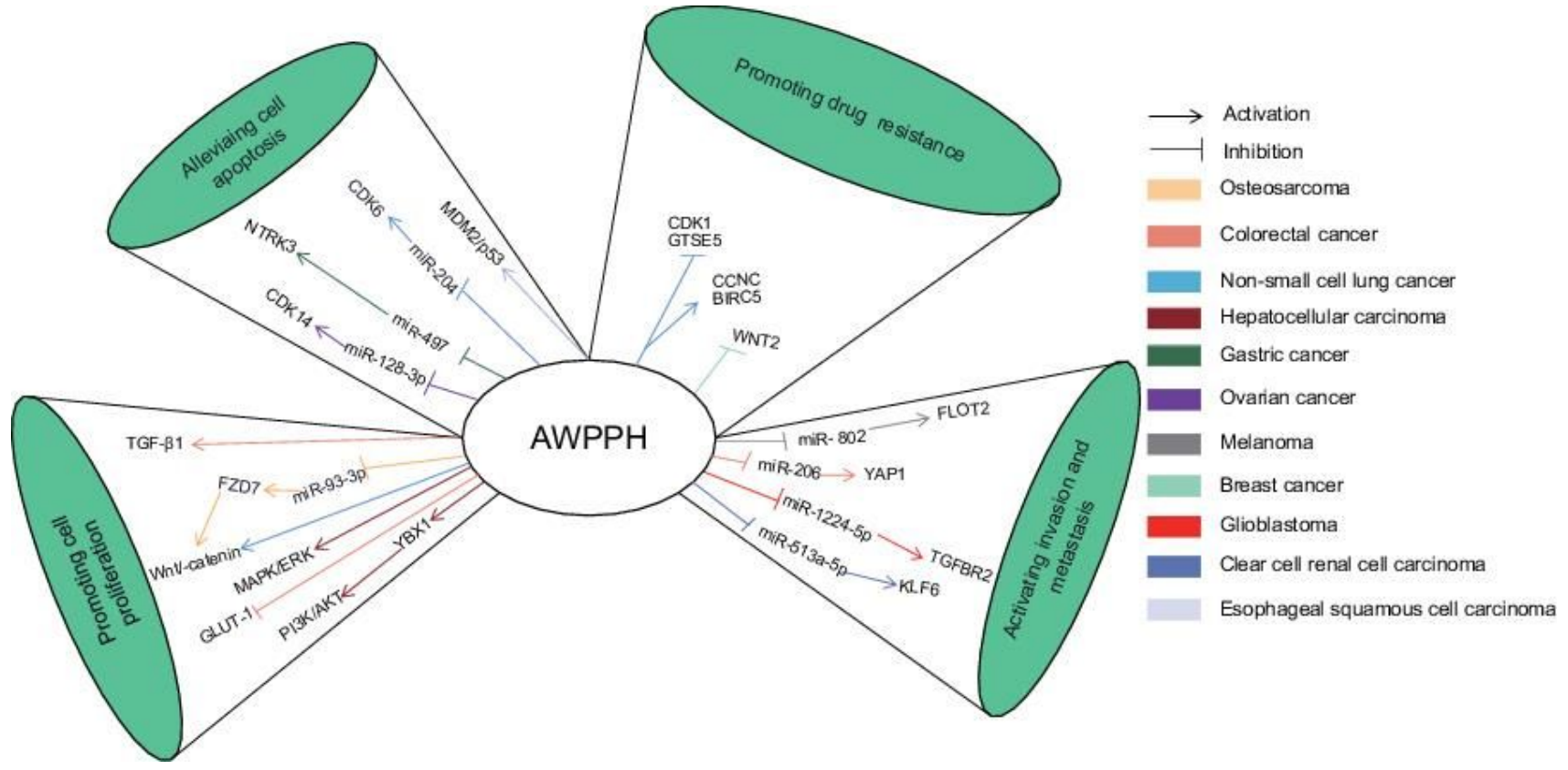

\section{Figure 8}

Schematic diagrams of various molecules and signaling pathways associated with AWPPH in human cancers.

\section{Supplementary Files}

This is a list of supplementary files associated with this preprint. Click to download.

- PRISMA2009checklist.doc

- PRISMA2009checklist.doc 